\title{
Adsorption Studies of Oil Spill Clean-up Using Coconut Coir Activated Carbon (CCAC)
}

\author{
Ukpong Anwana Abel ${ }^{1, ~ *, ~ G u m u s ~ R h o d a ~ H a b o r ~}{ }^{2}$, Oboh Innocent Oseribho ${ }^{3}$ \\ ${ }^{1}$ Department of Chemical and Petrochemical Engineering, Akwa Ibom State University, Ikot Akpaden, Mkpat Enin L.G.A, Nigeria \\ ${ }^{2}$ Department of Petroleum and Chemical Engineering, Niger Delta University, Wiberforce Island, Bayelsa State, Nigeria \\ ${ }^{3}$ Department of Chemical and Petroleum Engineering, University of Uyo, Uyo, Nigeria
}

Email address:

anwana.abel@gmail.com (U. A. Abel), anwanaukpong@aksu.edu.ng (U. A. Abel)

${ }^{*}$ Corresponding author

\section{To cite this article:}

Ukpong Anwana Abel, Gumus Rhoda Habor, Oboh Innocent Oseribho. Adsorption Studies of Oil Spill Clean-up Using Coconut Coir Activated Carbon (CCAC). American Journal of Chemical Engineering. Vol. 8, No. 2, 2020, pp. 36-47. doi: 10.11648/j.ajche.20200802.11

Received: March 25, 2020; Accepted: April 9, 2020; Published: April 23, 2020

\begin{abstract}
The adsorption of crude oil from water by using Potassium hydroxide (KOH) prepared from coconut coir activated carbon $\mathrm{CCAC}_{\mathrm{KOH}}$ was investigated by batch adsorption under varying parameters such as adsorbent dosage, contact time, initial oil concentration, temperature and agitation speed. The morphological modification significantly increased the hydrophobicity of the adsorbent, thus creating a CCAC with a much better adsorption capacity for crude oil removal having a maximum adsorption capacity of $4859.5 \mathrm{mg} / \mathrm{g}$ at $304 \mathrm{~K}$ as evidently proven by FTIR and SEM analysis. The experimental results showed that the percentage of crude oil removal increased with an increase in adsorbent dosage, contact time and decrease in initial oil concentration. The experimental isotherm data were analysed using Langmuir, Freundlich, Temkin, Toth, Sip and RedlichPeterson isotherm equations and the best fitted isotherm model was Freundlich model with a high correlation coefficient $\left(\mathrm{R}^{2}=\right.$ 0.999). The kinetic data were properly fitted into various kinetic models with Pseudo-second order model showing best fit having a correlation coefficient $\left(\mathrm{R}^{2}=0.999\right)$ and Boyd model revealed that the adsorption was controlled by internal transport mechanism and film-diffusion was the major mode of adsorption. The crude oil adsorption was chemisorption and endothermic in nature $\left(\Delta \mathrm{H}^{\circ}\right.$ $=134 \mathrm{KJ} / \mathrm{mol} . \mathrm{K})$ and the positive value of entropy $\left(\Delta \mathrm{S}^{\circ}=0.517 \mathrm{KJ} / \mathrm{mol} . \mathrm{K}\right)$ showed an increase in disorder and randomness at the adsorbent-adsorbate interface during the adsorption of crude oil from water. The decrease in Gibbs energy $\left(\Delta \mathrm{G}^{\circ}\right)$ with increasing temperature indicated an increase in the feasibility and spontaneity of the adsorption at higher temperatures. The prepared adsorbent showed significant capability to be used as a low-cost, re-generable and eco-friendly adsorbent in oil spill clean-up.
\end{abstract}

Keywords: Coconut Coir Activated Carbon, Adsorbent, Hydrophobicity, Oleophilicity, Adsorption Capacity, $\%$ Removal of Crude Oil, Adsorption Studies, Chemical Activation.

\section{Introduction}

Since the evolution and advancement in the field of oil and gas technology, the hazards associated with oil spills to marine and freshwater environments have significantly increased due to the increase in production, exploration, transportation, distribution, storage and other related processes of crude oil all over the world. Hence, oil spills have become a worldwide concern due to its environmental and economic impact [1]. Hazardous chemicals are released from oil spills such as polycyclic aromatic hydrocarbons which have harmful effect to aquatic and human lives and may require too much time before the effect can be reversed [2]. Numerous ecological disasters have been caused by undesirable petroleum products spills, for example in 1970 and 1971 - the Gulf of Mexico drilling rig incidents; 1978 - the breakdown of the Piper Alpha Platform in the North Sea; 1989 - the Exxon Valdez spill in Alaska; 1991 operation Desert Storm that released a huge amount of oil into the Arabian Gulf; 1999 - the Erika spill in France; 2002 - the Prestige spill in Spain; 2010 - the British Petroleum (BP) Deepwater Horizon spill in the Gulf of Mexico, and regular petroleum leakages in the Niger Delta region of Nigeria since 1958 [3]. Apart from financial losses, such incidents cause huge and sustained devastation in Earth's ecosystems and harm living 
organisms [4]. These environmental disasters together with some local scale incidents seriously endanger the environment; thus, it becomes imperative in improving oil spill clean-up methods and developing new materials which can be applied for this purpose. The main oil spill response techniques include burning, skimming, use of dispersants and sorbent materials [5]. However, it is pertinent to note that there is no absolutely perfect technique to be used to tackle a complicated problem such as oil spillage has these techniques have their inherent limitations. Among these techniques, adsorption is considered as a simple, applicable and low cost technique for oil spill treatment in comparison with other used techniques. In general, sorbents are used most effectively during the final stage of oil spill clean-up and for the recovery of small pools of oil which cannot be easily recovered using other oil clean-up techniques. Sorbent is an insoluble material or mixture of materials used to recover liquids through the mechanisms of absorption or adsorption, or both [6]. The ideal sorbent material used for oil spill treatment should have the following characteristics: oleophilicity, enduring, reusable, biodegradable, has high uptake capacity and high selectivity of oil [7]. Sorbents are materials that have high affinity to attract oil and also repel water. Sorbent can be grouped as inorganic minerals and synthetic, natural and organic (agricultural) products. Agricultural sorbents are cheap, efficient, environmentally friendly, and easy to deploy. However, their efficiency is dependent on sorption capacity, density, wettability, retention rate and recyclability and examples are cotton, straws, corn cobs, coconut shells, kenaf, kapok fibres, rice coir and silkworm cocoon, hay, sawdust, bagasse, gorse, and dried palm fronds [8]. However, it is of imperative importance to study the applicability of using these biodegradable waste materials as natural sorbents for oil spill treatment and comparing them with other methods of oil spill clean-up from different water surfaces rather than disposing them off [9]. Coconut fibres can float on the water surface for a very long period of time to collect oil adequately. It has been reported that coconut coir/coir sorption capacity is higher than commercial synthetic organic material from propylene [10]. Similarly, kapok, rice coir, banana trunk fibre, acetylation of raw cotton, and cotton grass fibre, have been reported to be efficient as oil sorbents [11]. The conversion of coconut coir into activated carbon serves a dual purpose. Firstly, the unwanted agricultural waste is converted into useful, valueadded adsorbents and secondly, the use of agricultural byproducts represents a potential source of adsorbents which will contribute to solving part of the wastewater treatment problem in Nigeria [12]. However, not many studies have been carried out on coconut coir-based activated carbon for oil spill clean-up. Some of them are adsorption of arsenic on copper impregnated coconut coir carbon [13], preparation of activated carbon from digested sewage sludge with the additive coconut coir using $\mathrm{ZnCl}_{2}$ as activating agent [10], production of activated carbons from coconut fibres for removal of phenol, Acid Red 27 dye and $\mathrm{Cu}^{2+}$ ions [14] and preparation of activated carbon from coconut coir for adsorption of basic dye [12]. The most important characteristic of an activated carbon is its adsorption capacity or uptake which is highly influenced by the activated carbon preparation conditions. This is because activated carbon preparation variables such as activation temperature, activation time and chemical impregnation ratio influences the pore development and surface characteristics of the activated carbon produced $[12,10]$. Hence, the objective of this research is to determine the adsorption capacity and \% removal of crude oil spill using coconut coir activated carbon (CCAC).

\section{Experimental Methods}

\subsection{Materials}

The coconut coir was obtained from Etinan main market in Etinan LGA, Akwa Ibom State, Nigeria. The crude oil used was obtained from Mobil Producing Nigeria Unlimited (MPNU).

\subsection{Preparation of Adsorbent}

The coconut coir samples were washed several times using tap water and finally with distilled water and thereafter dried to constant weight at $105^{\circ} \mathrm{C}$ for $24 \mathrm{~h}$ in a laboratory drying oven (DHG-9101 model) to remove excess water content and some volatile component. Then, the dried sample was crushed and sieved into smaller size particle (1-2mm) and stored at room temperature for impregnation. The crushed coconut coir sample was carbonized in a muffle furnace at a temperature of $600^{\circ} \mathrm{C}$ for $2 \mathrm{~h}$ in the absence of oxygen and the carbonized sample was pre-treated with $\mathrm{KOH}$ pellets at an Impregnation Ratio (I.R) of 1:2. In this case, $63.7 \mathrm{~g}$ of CCAC was pre-treated with $31.8 \mathrm{~g}$ of $\mathrm{KOH}$ dissolved in 1.0 $\mathrm{L}$ of deionized water as calculated using Equation 1.

$$
\mathrm{I} . \mathrm{R}=\frac{\mathrm{W}_{\text {кон }}}{\mathrm{W}_{\mathrm{A} . \mathrm{C}}}
$$

where; $\mathrm{W}_{\mathrm{KOH}}$ is the dry weight $(\mathrm{g})$ of $\mathrm{KOH}$ pellets and $\mathrm{W}_{\mathrm{A.C}}$ is the dry weight $(\mathrm{g})$ of activated carbon. The mixture was then dried in a laboratory drying oven at $105^{\circ} \mathrm{C}$ for $12 \mathrm{~h}$ to remove moisture and was activated in a muffle furnace at a temperature of $800{ }^{\circ} \mathrm{C}$ for $1 \mathrm{~h}$. The CCAC produced was cooled to room temperature and washed with $0.1 \mathrm{M} \mathrm{HCl}$ solution to remove any residual ash content and with distilled water until the $\mathrm{pH}$ of washing solution reached 6-7. The prepared CCAC was then oven dried at temperature of $105^{\circ} \mathrm{C}$ for $2 \mathrm{~h}$ and further crushed and sieved into $63-500 \mu \mathrm{m}$ particle sizes and then stored in a desiccator until needed for the adsorption experiment.

\subsection{Proximate Analysis}

In this study, proximate analysis of the CCAC gave details about the moisture content by using the standard method of ASTM D 2867-91 [15], the volatile matter content was determined according to the standard method of ASTM D 5832-98 [16], the ash content was determined according to the standard method of ASTM D 2866-94 [17], the bulk density was determined according to the tamping procedure of ASTM D 2854-96 [18], pH was determined using the standard method of ASTM D 3838-80 [19] and the specific surface area was estimated using Sear's method [20].

\subsection{Characterization of Adsorbent}


Scanning electron microscope (SEM) micrographs of CCAC were obtained by using SEM machine (JEOL JSM$6300 \mathrm{~F}$ field emission) when about $20 \mathrm{mg}$ of the dried adsorbent sample was sputter-coated with a gold layer in a sputter machine (quantum sputter) for a period of $90 \mathrm{~s}$ and the SEM machine was allowed to stabilize for $2 \mathrm{~min}$ before setting the parameters to be used. Imaging of the sample was done at $15 \mathrm{kV}$, pressure at $0.003 \mathrm{~Pa}$ and set at 1000 magnification. Fourier transform infrared spectroscopy (FTIR) of CCAC was done by using an FTIR spectrometer (Model FTIR-2000, Perkin Elmer) where $150 \mathrm{mg} \mathrm{KBr}$ disks containing approximately $2 \%$ of the adsorbent sample were prepared shortly before recording the FTIR spectra in the range of 400-4000.0 $\mathrm{cm}^{-1}$ and with a resolution of $4 \mathrm{~cm}^{-1}$. The resulting spectra were average of 30 scans.

\subsection{Preparation of Simulated Oil Spill}

A typical small oil spill scenario of $19440 \mathrm{mg} / \mathrm{L}$ of initial concentration was simulated by pouring $19.44 \mathrm{~g}$ of crude oil into $1000 \mathrm{~mL}$ of brine water ( 0.035 wt. $\% \mathrm{NaCl} \mathrm{Conc.).} \mathrm{The}$ immiscible solution was mechanically agitated for $15 \mathrm{~min}$ using a heavy duty blender (waring commercial blender) to form an emulsified solution as shown in Figure A1.

\subsection{Preparation of Calibration Curve}

A serial dilutions of the stock solution of simulated oil spill were prepared for different concentrations of $(2-50 \mathrm{mg} / \mathrm{L})$ and was mechanically agitated for 15 min using a heavy duty blender to form an emulsified solution which was subsequently analysed using a UV-Vis spectrophotometer (Spectrum Lab 23A, Gallenkomp, England) at a wavelength of $380 \mathrm{~nm}$ to obtain the corresponding absorbance values and a calibration curve of Absorbance values against Concentration was plotted.

\subsection{Batch Adsorption Equilibrium and Kinetics Studies}

Each experimental study was carried out by measuring 250 $\mathrm{mL}$ of the simulated oil spill of $19440 \mathrm{mg} / \mathrm{L}$ initial concentration into a $500 \mathrm{~mL}$ beaker. The batch adsorption studies were performed for different parameters such as adsorbent dosage, adsorbate concentration, contact time, agitation speed, particle size and temperature. The batch adsorption equilibrium studies were performed by measuring exactly $1.0 \mathrm{~g}$ of $\mathrm{CCAC}_{\mathrm{KOH}}$ into a $500 \mathrm{~mL}$ beaker containing varying initial concentration $(3888,11664,19440,27216$ and $34992 \mathrm{mg} / \mathrm{L}$ ) of the simulated oil spill. The mixture was agitated in an orbital shaker (Rotamax 120, Reidolph) at 20 $\mathrm{rpm}$ and at a temperature of $25^{\circ} \mathrm{C}$ for $1 \mathrm{~h}$ which was necessary to attain equilibrium. The adsorbed $\mathrm{CCAC}_{\mathrm{KOH}}$ was filtered off using a micro-pore filter/suction funnel and the residual oil-in-water solution was homogenized using a heavy duty blender for $15 \mathrm{~min}$ to form an emulsified solution. The equilibrium concentration of the emulsified solution for each measured sample was determined using a UV-Vis spectrophotometer at a wavelength of $380 \mathrm{~nm}$ [21]. Similarly, the batch adsorption kinetic studies were carried out by measuring exactly $1.0 \mathrm{~g}$ of $\mathrm{CCAC}_{\mathrm{KOH}}$ into a $500 \mathrm{~mL}$ beaker containing $19440 \mathrm{mg} / \mathrm{L}$ initial concentration of the simulated oil spill and agitating it in an orbital shaker at $20 \mathrm{rpm}$ and at a temperature of $25^{\circ} \mathrm{C}$ for varying contact time of $(15,30,45$, $60,75,90,105$ and $120 \mathrm{~min})$. The batch adsorption experimental set-ups for the removal of crude oil using CCAC are shown in Figures A2 and A3.

For each batch run, the amount of crude oil adsorbed per unit mass of activated carbon at equilibrium $\mathrm{q}_{\mathrm{e}},(\mathrm{mg} / \mathrm{g})$, at time, $\mathrm{t}, \mathrm{q}_{\mathrm{t}}(\mathrm{mg} / \mathrm{g})$ and the $\%$ removal of crude oil were determined using Equation 2, Equation 3 and Equation 4 respectively.

$$
\begin{gathered}
q_{e}=\frac{\left(C_{o}-C_{e}\right) * V}{M} \\
q_{t}=\frac{\left(C_{o}-C_{t}\right) * V}{M} \\
\% \text { removal of crude oil }=\frac{\left(C_{o}-C_{e}\right) * 100}{C_{o}}
\end{gathered}
$$

Where $\mathrm{C}_{\mathrm{o}}=$ initial concentration of solution $(\mathrm{mg} / \mathrm{L}), \mathrm{C}_{\mathrm{e}}=$ equilibrium concentration $(\mathrm{mg} / \mathrm{L}), \mathrm{C}_{\mathrm{t}}=$ concentration of solution at time, $\mathrm{t},(\mathrm{mg} / \mathrm{L}), \mathrm{V}=$ volume of the solution $(\mathrm{mL})$ and $\mathrm{M}=$ mass of adsorbent used $(\mathrm{g})$.

\subsection{Thermodynamics Studies}

The thermodynamics studies were conducted similarly to that of batch equilibrium and kinetics experiments by measuring exactly $1.0 \mathrm{~g}$ of $\mathrm{CCAC}_{\mathrm{KOH}}$ into a $500 \mathrm{~mL}$ beaker containing $19440 \mathrm{mg} / \mathrm{L}$ initial concentration of the simulated oil spill and agitating it in a shaking water bath (Model DKZ. XMTD-8222; Gallenhamp) at $20 \mathrm{rpm}$ and at varying temperatures of $\left(23,25,27,29\right.$ and $\left.31^{\circ} \mathrm{C}\right)$ for $1 \mathrm{~h}$; the temperature range was used to depict the sea surface temperature (SST) in the Niger Delta region of Nigeria [22]. The adsorbed activated carbon was filtered off using a micropore filter/suction funnel and the residual oil-in-water solution was homogenized using a heavy duty blender for 15 min to form an emulsified solution. The concentration of the emulsified solution for each measured sample was determined using a UV-Vis spectrophotometer at a wavelength of $380 \mathrm{~nm}$. The thermodynamics parameters such as Gibbs free energy change $\left(\Delta \mathrm{G}^{\mathrm{o}}\right)$, enthalpy change $\left(\Delta \mathrm{H}^{\mathrm{o}}\right)$, entropy change $\left(\Delta S^{\circ}\right)$ and activation energy were used to describe the thermodynamic behaviour of the adsorption of crude oil onto $\mathrm{CCAC}_{\mathrm{KOH}}$ as shown in Equation 5, Equation 7 and Equation 8 respectively.

The Gibbs free energy change $\left(\Delta G^{0}\right)$ was calculated by using Equation 5.

$$
\Delta G^{o}=-R T \operatorname{In} K_{c}
$$

Where; $\mathrm{K}_{\mathrm{c}}$ is the equilibrium constant of the adsorption which is obtain from Equation 6. 


$$
K_{c}=\frac{C_{e}(\text { adsorbent })}{C_{e}(\text { solution })}
$$

where $\mathrm{C}_{\mathrm{e}}$ (adsorbent) and $\mathrm{C}_{\mathrm{e}}$ (solution) are the equilibrium concentration of the crude oil on the adsorbent and in the solution respectively.

The enthalpy change $\left(\Delta H^{\circ}\right)$ and entropy change $\left(\Delta S^{\circ}\right)$ were estimated from the slope and intercept of the plot of In $\mathrm{K}_{\mathrm{c}}$ versus $(1 / T)$ respectively as shown in Equation 7.

$$
\text { In } K_{c}=\frac{\Delta S^{o}}{R}-\frac{\Delta H^{o}}{R T}
$$

Also, the activation energy was calculated from the slope of the plot of In $K_{c}$ versus $(1 / T)$ as shown in Equation 8.

$$
\text { In } K_{c}=\operatorname{In} A-\frac{E a}{R}\left(\frac{1}{T}\right)
$$

\section{Results and Discussion}

\subsection{Characterization of Adsorbent}

Table 1. Proximate analysis of CCAC.

\begin{tabular}{ll}
\hline Proximate analysis & CCAC $_{\mathbf{K O H}}$ \\
\hline Specific surface area $\left(\mathrm{m}^{2} / \mathrm{g}\right)$ & 691.800 \\
Moisture content $(\%)$ & 1.000 \\
Bulk density $\left(\mathrm{g} / \mathrm{cm}^{3}\right)$ & 0.132 \\
Volatile matter content $(\%)$ & 1.000 \\
Ash content $(\%)$ & 2.000 \\
$\mathrm{Ph}$ & 6.690 \\
\hline
\end{tabular}

As seen in Table 1, CCAC had a low ash content of $2.0 \%$ which implies that it can be used to produce high yield and porous carbon. According to Daud et al. (2004) and Yang et al. (2010), different organic materials can be transformed into highly carbonaceous activated carbon as a typical ash content of activated carbons is around 5-6\% [23 and 24]. A small increase in ash content causes a decrease in adsorptive properties of activated carbons and the presence of ash inhibits surface development of the activated carbon [25]. Likewise, high ash content is undesirable for activated carbon since it reduces the mechanical strength of carbon and thus affects the adsorptive capacity. The moisture content of
$1.0 \%$ showed a decrease as the temperature increased, hence for some commercial carbons, in order to meet standard requirement for packaging, transporting and storing the moisture content should be $<5 \%$ [20].

\subsection{FT-IR Analysis of the Adsorbent}

The Fourier Transform-Infrared (FT-IR) spectra analysis of $\mathrm{CCAC}_{\mathrm{KOH}}$ before and after adsorption revealed the presence of several peaks indicating the presence of different functional groups within the wavelength of $600-4000 \mathrm{~cm}^{-1}$ as shown in Table 2 . The FT-IR spectra of the $\mathrm{CCAC}_{\mathrm{KOH}}$ before adsorption revealed a broad and intense absorption peak between 3520.6 to 3666.1 $\mathrm{cm}^{-1}$ which represent the presence of $-\mathrm{OH}$ stretching of alcohol group [26]. The medium intense absorption peak from 3212.7 to $3417.5 \mathrm{~cm}^{-1}$ corresponds to the $-\mathrm{NH}$ stretching of amine group. The peaks between 2875.3 to $2961.5 \mathrm{~cm}^{-1}$ and 3030.5 to 3092.8 $\mathrm{cm}^{-1}$ were attributed to the presence of $\mathrm{C}-\mathrm{H}$ symmetric or asymmetric stretching of alkane and alkene groups respectively $[27,28]$. A strong and broad absorption peak from 2508.3 to $2694.6 \mathrm{~cm}^{-1}$ indicates the presence of $-\mathrm{OH}$ stretching of carboxylic acid and also the peak at 2057.0 to $2119.8 \mathrm{~cm}^{-1}$ was observed to be associated with $\mathrm{C} \equiv \mathrm{C}$ stretching of alkyne group. The peaks between 1462.4 to $1560.1 \mathrm{~cm}^{-1}$ and 1658.5 to 1762.7 $\mathrm{cm}^{-1}$ revealed the presence of $\mathrm{C}=\mathrm{C}$ stretching and $\mathrm{C}=\mathrm{O}$ stretching of aromatic benzene ring group and carbonyl group respectively [29]. The peaks between 1086.2 to $1140.6 \mathrm{~cm}^{-1}$ and 1194.4 to $1248.3 \mathrm{~cm}^{-1}$ indicated the presence of a strong $\mathrm{C}-\mathrm{O}$ stretching and C-N stretching of alcohol group and amine group respectively [30, 31]. The FT-IR spectra of $\mathrm{CCAC}_{\mathrm{KOH}}$ after adsorption exhibited similar characteristics as the spectra of $\mathrm{CCAC}_{\mathrm{KOH}}$ before adsorption except for slight increment/ enhancement in the absorption peaks and intensities due to the crude oil adsorption process as illustrated in Table 2. An enhanced absorption peaks were clearly observed at 3519.7 to $3711.4 \mathrm{~cm}^{-1}$ (presence of a strong, broad O-H stretching of the alcohol group), 3284.8 to $3422.2 \mathrm{~cm}^{-1}$ (N-H stretching of amine group), 3048.9-3112.8 $\mathrm{cm}^{-1}$ (C-H stretching of alkene groups), 2816.1 to $2995.0 \mathrm{~cm}^{-1}$ (C-H stretching of alkane group), 2552.1 to $2761.4 \mathrm{~cm}^{-1}$ (very strong, broad $-\mathrm{OH}$ stretching of carboxylic acid), 2001.6 to $2196.2 \mathrm{~cm}^{-1}$ ( $\mathrm{C} \equiv \mathrm{C}$ stretching of alkyne group), 1635.3 to $1704.8 \mathrm{~cm}^{-1}(\mathrm{C}=\mathrm{O}$ stretching of carbonyl group), 1521.1 to $1579.5 \mathrm{~cm}^{-1} \quad(\mathrm{C}=\mathrm{C}$ stretching of aromatic benzene ring group), 1132.5 to $1222.3 \mathrm{~cm}^{-1}$

\begin{tabular}{|c|c|c|c|}
\hline Functional groups present in the Adsorbents & $\begin{array}{l}\text { Absorption peaks of raw } \\
\text { coconut coir }\left(\mathrm{cm}^{-1}\right)\end{array}$ & $\begin{array}{l}\text { Absorption peaks of } \mathrm{CCAC}_{\mathrm{KOH}} \\
\text { before Adsorption }\left(\mathrm{cm}^{-1}\right)\end{array}$ & $\begin{array}{l}\text { Absorption peaks of } \mathrm{CCAC}_{\mathrm{KOH}} \\
\text { after Adsorption }\left(\mathrm{cm}^{-1}\right)\end{array}$ \\
\hline -OH stretching of alcohol group & 3372 & $3520.6-3666.1$ & $3519.7-3711.4$ \\
\hline -NH stretching of amine group & - & $3212.7-3417.5$ & $3284.8-3422.2$ \\
\hline $\mathrm{C}-\mathrm{H}$ asymmetric stretching of alkene group & - & $3030.5-3092.8$ & 3048.9-3112.8 \\
\hline $\mathrm{C}-\mathrm{H}$ symmetric stretching of alkane group & 2914 & $2875.3-2961.5$ & $2816.1-2995.0$ \\
\hline -OH stretching of carboxylic acid group & - & $2508.3-2694.6$ & 2552.1-2761.4 \\
\hline $\mathrm{C} \equiv \mathrm{C}$ stretching of alkyne group & - & 2057.0-2119.8 & 2001.6-2196.2 \\
\hline $\mathrm{C}=\mathrm{O}$ stretching of carbonyl group & 1652 & $1658.5-1762.7$ & $1635.3-1704.8$ \\
\hline $\mathrm{C}=\mathrm{C}$ stretching of alkene group & 1638 & - & - \\
\hline $\mathrm{C}=\mathrm{C}$ stretching of aromatic benzene ring group & 1457 & $1462.4-1560.1$ & $1521.1-1579.5$ \\
\hline C-O stretching of alcohol group & 1068 & $1086.2-1140.6$ & $1132.5-1222.3$ \\
\hline
\end{tabular}
(strong $\mathrm{C}-\mathrm{O}$ stretching of alcohol group).

Table 2. FT-IR of CCAC. 


\subsection{Surface Morphology Analysis of the Adsorbent}

Scanning electron microscopy (SEM) has been extensively used to study the surface morphology of activated carbons. The surface morphology of raw/untreated coconut coir, treated/modified coconut coir, treated/modified $\mathrm{CCAC}_{\mathrm{KOH}}$ after adsorption were observed based on the SEM images presented in Figures 1(a) to 1(c). Based on Figure 1(a), the raw coconut coir was observed to have tiny hole-like pores

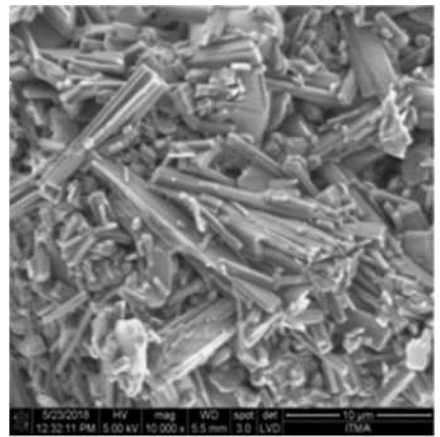

(a)

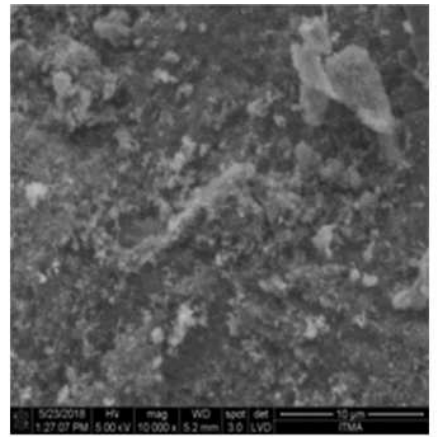

(b) with an uneven porosity and also rod-like structure with irregular sizes. The sharp edges on the structure indicate that the raw coconut coir has good crystallinity. As seen in Figures 1(a) and (b), the surface morphology of untreated coconut coir material was different from the treated one as the treatment significantly altered the physicochemical properties and porosity of the adsorbent material.

Figure 1. SEM Image of (a) raw/untreated coconut coir before chemical activation (b) treated/modified coconut coir after chemical activation (c) treated/modified $\mathrm{CCAC}_{\mathrm{KOH}}$ after adsorption.

The treatment with alkaline partially removed the protective thin wax (cellulose, hemicellulose and lignin) on adsorbent surface as observed in Figure 1(b) and it also showed the appearance of perforation due to the leaching of structural materials that exposed the active sites on the adsorbent surface; thus, creating available pores and large internal surface area for the adsorption to take place on the adsorbent surfaces $[32,33]$ and also the modified surface appeared to be rough, indicating that the surface had been covered with organic molecular layer [28].

The Scanning electron micrographs (SEM) of $\mathrm{CCAC}_{\mathrm{KOH}}$ after adsorption as shown in Figure 1(c) showed $\mathrm{CCAC}_{\mathrm{KOH}}$ to possess uneven and irregular surface with considerable layers of rough heterogeneous pores which offered high possibility for crude oil adsorption. Thus, ascertained that the relative porous surface with wide ranging cracks had clearly visible macro-pores which aid in facilitating the easy diffusion of crude oil molecules into the pore structures and surface of the adsorbent.

\subsection{Factors Influencing the Batch Adsorption Equilibrium Studies}

The batch adsorption equilibrium studies for the adsorption of crude oil onto $\mathrm{CCAC}_{\mathrm{KOH}}$ were investigated as follows:

\section{i. Effect of Contact time}

From Figure 2, the adsorption of crude oil onto $\mathrm{CCAC}_{\mathrm{KOH}}$ was observed to be rapid at the initial stage of contact time 15 to $30 \mathrm{~min}$ and thereafter, continued at a slower rate before finally attaining saturation at an equilibrium contact time of $105 \mathrm{~min}$ [34]. The initial high adsorption capacity and \% removal of crude oil can be attributed to the existence of empty active sites on the surface of $\mathrm{CCAC}_{\mathrm{KOH}}$ and also due to the reducing strong attractive forces between the crude oil molecules and the adsorbent as the contact time increased [35, 28].

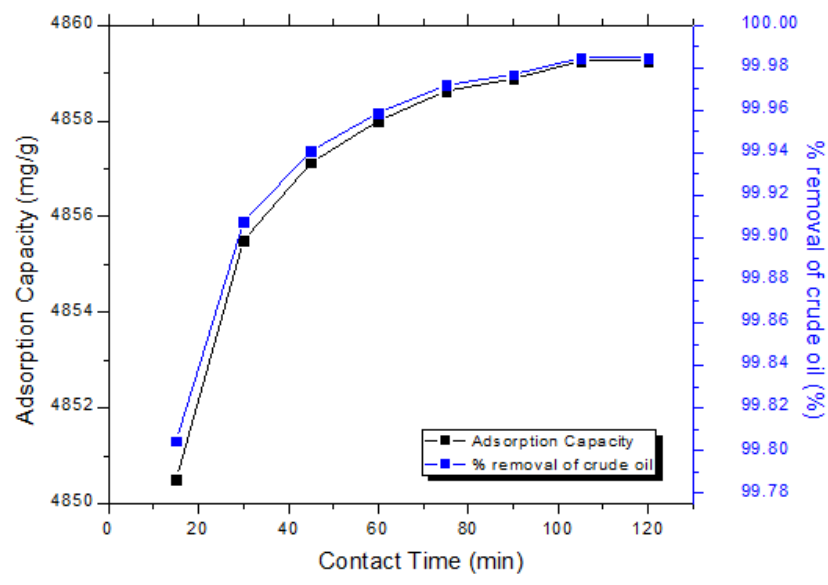

Figure 2. The effect of contact time on the adsorption of crude oil onto $C C A C_{\mathrm{KOH}}$.

It was also observed that the adsorption capacity and \% removal of crude oil remained constant after $105 \mathrm{~min}$ ostensibly due to the saturation of $\mathrm{CCAC}_{\mathrm{KOH}}$ surface with crude oil particles as well as the equilibrium between adsorption and desorption process that occurred after the saturation [36]. $\mathrm{CCAC}_{\mathrm{KOH}}$ showed high adsorption capacity of $4859.25 \mathrm{mg} / \mathrm{g}$ and percentage removal of crude oil of $99.98457 \%$ due to a large surface area being available for the adsorption of crude oil, thereby resulting in a fast diffusion onto the external material surface which was followed by fast pore diffusion into the intra-particle matrix up to attain the equilibrium at $105 \mathrm{~min}$ [37].

\section{ii. Effect of Adsorbent Dosage}

The effect of adsorbent dosage on the adsorption of crude oil was studied by the application of adsorbent dosage 
between $0.5 \mathrm{~g}$ to $3.0 \mathrm{~g}$ for $\mathrm{CCAC}_{\mathrm{KOH}}$. As shown in Figure 3, an increase in the adsorbent dosage led to a decrease in the adsorption capacity of the adsorbent but increased the \% removal of crude oil. The increase in active sites led to a higher \% removal of crude oil but lowered the crude oil adsorption capacity per unit mass of adsorbent. This is due to the greater number of active sites available on the surfaces of $\mathrm{CCAC}_{\mathrm{KOH}}$ for crude oil to be adsorbed at a higher adsorbent dosage $[38,35]$, thus leading to a higher interaction between crude oil particles and the adsorbents.

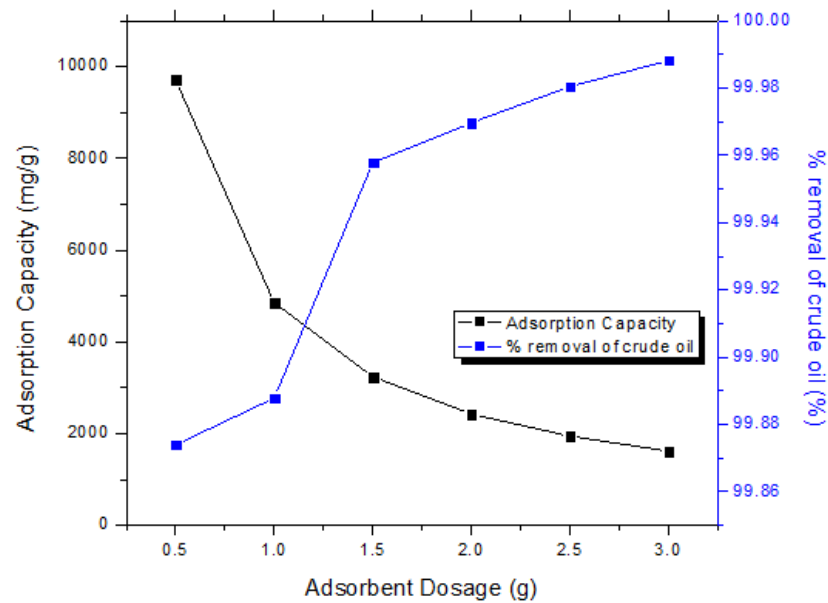

Figure 3. The effect of adsorbent dosage on the adsorption of crude oil onto ССАС

In addition, saturation effect also caused a decrease in the \% removal of crude oil when the maximum adsorption capacity had been reached [39]. However, at higher dose of adsorbent, the crude oil was permanently bounded onto the surfaces of the adsorbent thus; facilitating the storage and transport of waste material [40]. Meanwhile, the decrease in adsorption capacity was essentially due to the higher unsaturated adsorption sites available during adsorption process [41, 42].

\section{iii. Effect of Initial Crude Oil Concentration}

The effect of initial crude oil concentration on the adsorption of crude oil as shown in Figure 4 revealed that an increase in the initial crude oil concentration increased the adsorption capacity but decreased the $\%$ removal of crude oil due to the availability of active sites on the surfaces of the $\mathrm{CCAC}_{\mathrm{KOH}}$. As illustrated in Figure 4, at low initial crude oil concentration, $3888 \mathrm{mg} / \mathrm{L}$ for $\mathrm{CCAC}_{\mathrm{KOH}}$, the ratio of surface active sites to crude oil was high which led to more crude oil molecules interacting with the adsorbent to occupy the active sites on its surface; hence producing a high adsorption capacity of $971.925 \mathrm{mg} / \mathrm{g}$ and \% removal of crude oil of $99.99228 \%$ [43]. Conversely, when the initial crude oil concentration was increased, the number of active adsorption sites was not enough to accommodate crude oil molecules; thus leading to a lower adsorption capacity of $8746.45 \mathrm{mg} / \mathrm{g}$ and \% removal of crude oil of $99.98228 \%$ [43, 44]. At high initial oil concentration, oil occupied the sorbent surface thus saturation was reached much faster and high amount of unattached oil was left [45].

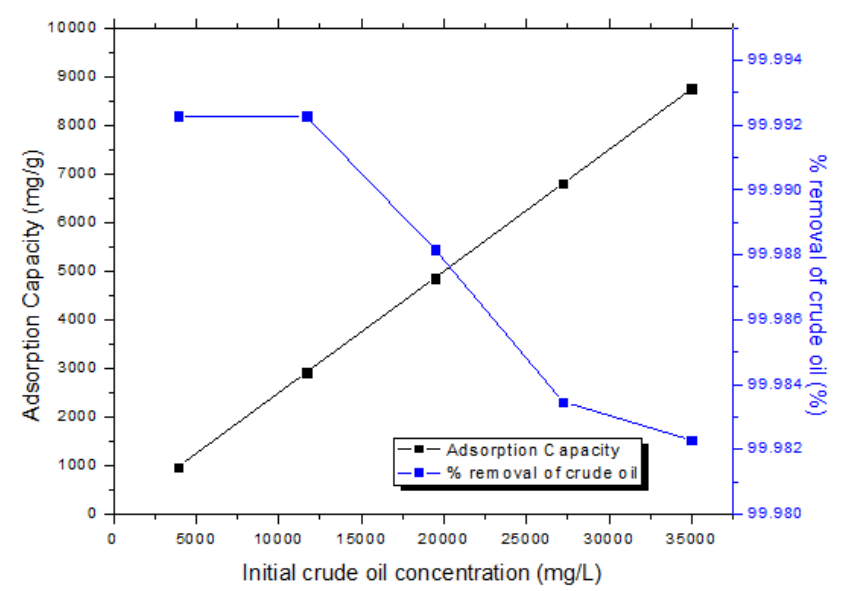

Figure 4. The effect of initial crude oil concentration on the adsorption of crude oil onto $\mathrm{CCAC} \mathrm{KOH}_{\mathrm{K}}$

\section{iv. Effect of Agitation Speed}

The effect of agitation speed on the adsorption of crude oil onto $\mathrm{CCAC}_{\mathrm{KOH}}$ was examined at 20-100 rpm for $60 \mathrm{~min}$. From the investigation presented in Figure 5 , it can be seen that an increase in the agitation speed increased both the adsorption capacity and the $\%$ removal of crude oil.

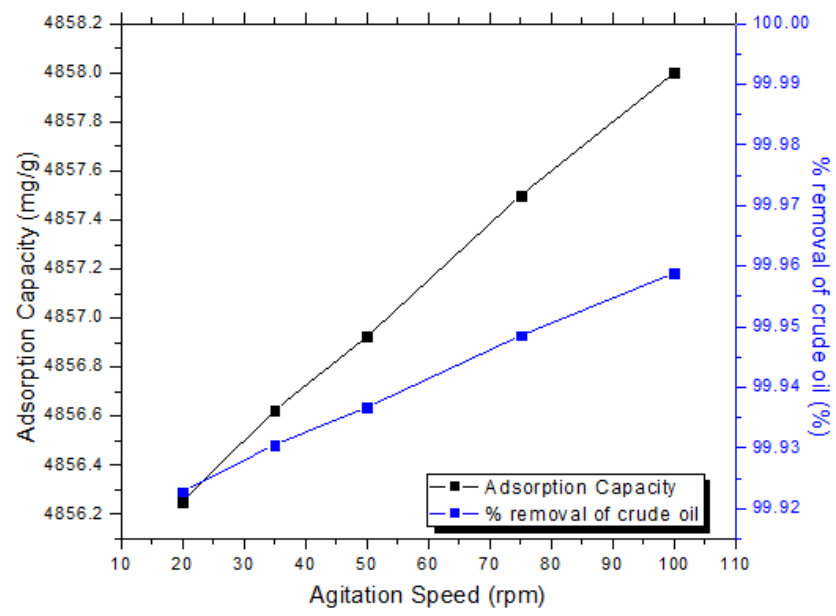

Figure 5. The effect of agitation speed on the adsorption of crude oil onto $\mathrm{CCA} \mathrm{C}_{\mathrm{KOH}}$.

Figure 5 showed that the rate of adsorption with removal of crude oil gradually increased with the agitation speed and the most notable adsorption occurred at $100 \mathrm{rpm}$. This validated the fact that an increase in agitation speed increased the rate of mass transfer leading to a reduction in surface film resistance, thereby allowing residual crude oil to easily reach the surface of the activated carbon [46]. This result also conformed to the study reported by Williams and Nur (2018), that there is no spread of sorbent in the sample at low agitation speed but rather it accumulates causing active sites to be buried [44]. The batch adsorption process was limited to an agitation speed of $\leq$ $100 \mathrm{rpm}$ in order to depict open water waves as any speed $100 \mathrm{rpm}$ was observed to be very turbulent and erratic in nature resulting in most of the adsorbed crude oil and adsorbent sticking to the walls of the beaker. 


\section{v. Effect of Temperature}

The effect of temperature on the adsorption of crude oil onto $\mathrm{CCAC}_{\mathrm{KOH}}$ was investigated at varying temperature as shown in Figure 6. It can be seen that the temperature increased with a corresponding increase in both adsorption capacity and \% removal of crude oil.

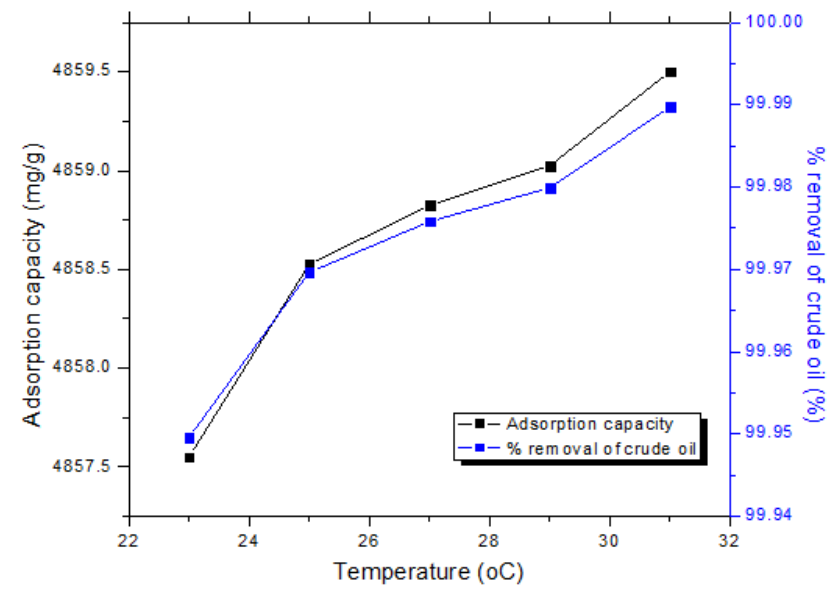

Figure 6. The effect of temperature on the adsorption of crude oil onto $C C A C_{\mathrm{KOH}}$.

As illustrated in Figure 6, an increase in the temperature resulted in a corresponding increase in both the adsorption capacity and percentage removal of crude oil. This was attributed to the weakening of hydrogen bonds and Van der Waals force of interaction at higher temperature which resulted in the strengthening of physical interaction between active sites of the crude oil molecules and adsorbent. Also, as the temperature increased, the rate of diffusion of crude oil molecules increased across the external boundary layer and the internal pores of the adsorbent particle because of the decrease in the viscosity of the solution and increase in the solubility of crude oil in water $[47,44]$. In addition, an increase in both \% removal of crude oil and adsorption capacity at higher temperature was possibly due to an increase in kinetic forces; that is, the mobility of the crude oil species inside the adsorbent matrix and also an increase in the porosity and in the total pore volume of the adsorbent [48]. It is worth noting that the temperature range $\left(23^{\circ} \mathrm{C}\right.$ to $\left.31^{\circ} \mathrm{C}\right)$ for the batch adsorption experiment was used to depict the sea surface temperature (SST) within the Niger Delta region of Nigeria [22].

\section{vi. Effect of Particle Size}

The effect of particle size on the adsorption of crude oil onto $\mathrm{CCAC}_{\mathrm{KOH}}$ was investigated at varying particle size as shown in Figure 7. It can be seen that an increase in the particle size led to a corresponding increase in both the adsorption capacity and \% removal of crude oil.

Figure 7 showed that an increase in the particle size ensued to a corresponding increase in both the adsorption capacity and $\%$ removal of crude oil. It can also be seen that the adsorption capacity increased with a decrease in the surface area of the adsorbent due to it possessing larger surface area, interstitial packing and the tendency of faster rate of adsorption. Hence, this validated the fact that the particle size distribution affects both adsorption capacity and rate of adsorption.

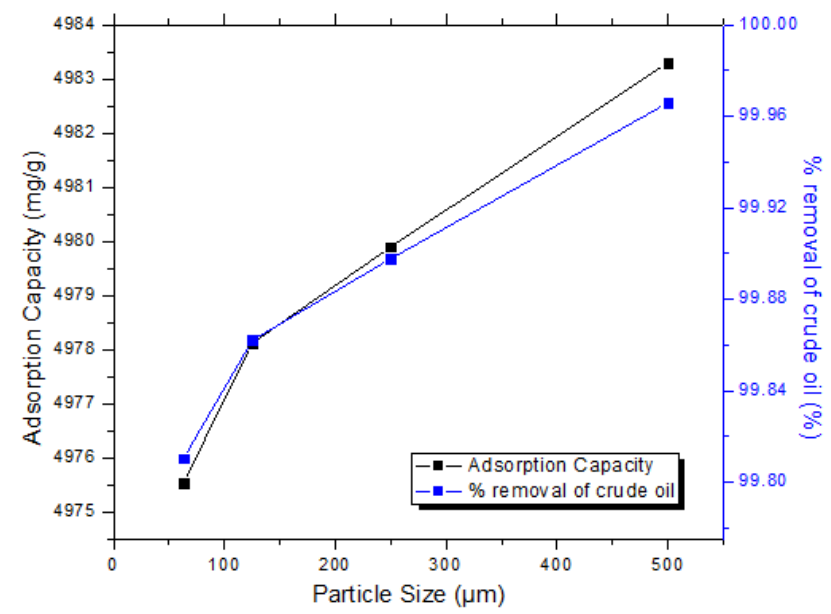

Figure 7. The effect of particle size on the adsorption of crude oil onto $C C A C_{\mathrm{KOH}}$.

\subsection{Batch Adsorption Isotherm}

The adsorption isotherm study was analysed using a plot of the adsorption capacity of crude oil at equilibrium, $\mathrm{q}_{\mathrm{e}}$ versus the equilibrium concentration of crude oil, $\mathrm{C}_{e}$ as illustrated in Figure 8 for crude oil adsorption onto $\mathrm{CCAC}_{\mathrm{KOH}}$. Six isotherm models namely; Langmuir, Freundlich, Temkin, Toth, Sip and Redlich-Peterson models were used and the applicability of these isotherm equations used to describe the adsorption process was determined using the correlation coefficients, $\mathrm{R}^{2}$ values and other error functions.

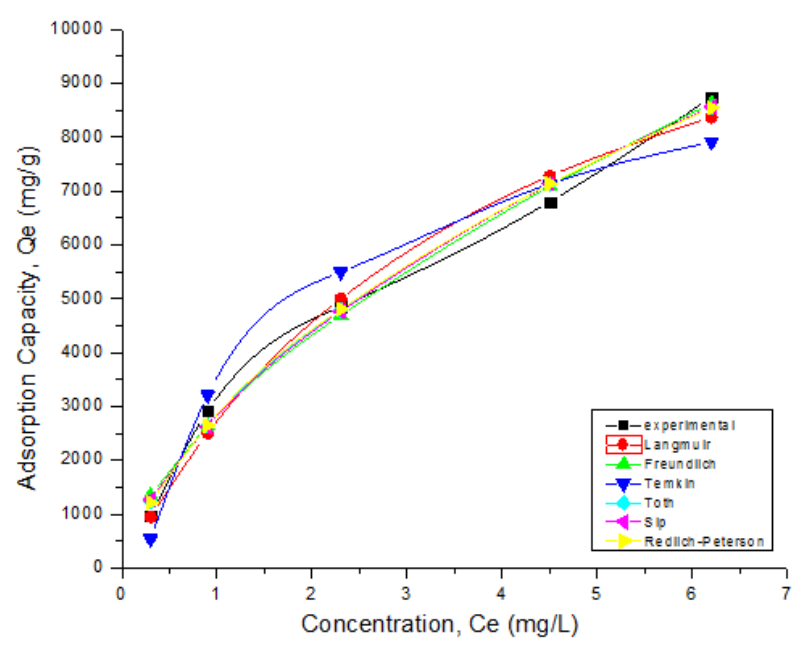

Figure 8. Isotherm plots for the adsorption of crude oil onto $C C A C_{K O H}$.

Figure 8 showed that Freundlich isotherm model yielded the highest adsorption capacity of $8628.07 \mathrm{mg} / \mathrm{g}$ for $\mathrm{CCAC}_{\mathrm{KOH}}$, followed by Sip, Toth, Redlich-Peterson and Langmuir Model. However, Temkin isotherm model had the least adsorption capacity of $7913.45 \mathrm{mg} / \mathrm{g}$ for $\mathrm{CCAC}_{\mathrm{KOH}}$. This was also evidently confirmed by [42] that Freundlich isotherm yielded the highest adsorption uptake of crude oil. 
Table 3. Adsorption Isotherm constant for the removal of crude oil using $C$ CAC ${ }_{K O H}$.

\begin{tabular}{|c|c|c|c|c|c|c|c|}
\hline \multirow{2}{*}{ Adsorbent } & \multicolumn{3}{|l|}{ Langmuir } & \multicolumn{4}{|l|}{ Freundlich } \\
\hline & $q_{m}(\mathrm{mg} / \mathrm{g})$ & $\mathrm{K}_{\mathrm{L}}(\mathrm{L} / \mathrm{mg})$ & $\mathbf{R}^{2}$ & $K_{f}(\mathrm{mg} / \mathrm{g})$ & $\mathbf{N}$ & $\mathbf{R}^{2}$ & \\
\hline $\mathrm{CCAC}_{\mathrm{KOH}}$ & $1.39 \times 10^{4}$ & 0.2440 & 0.986 & $2.82 \times 10^{3}$ & 1.63 & 0.999 & \\
\hline & Temkin & & & & Toth & & \\
\hline Adsorbent & $\mathrm{A}(\mathrm{L} / \mathrm{g})$ & B & $\mathrm{R}^{2}$ & $\mathrm{q}_{\mathrm{m}}(\mathrm{mg} / \mathrm{g})$ & $\mathrm{K}_{\mathrm{T}}(\mathrm{L} / \mathrm{mg})$ & $\mathrm{T}$ & $\mathrm{R}^{2}$ \\
\hline $\begin{array}{l}\mathrm{CCAC}_{\mathrm{KOH}} \\
\text { Adsorbent }\end{array}$ & 4.15743 & $\begin{array}{l}2.44 \times 10^{3} \\
\text { Sip }\end{array}$ & 0.9621 & $2.59 \times 10^{5}$ & $\begin{array}{l}0.52102 \\
\text { Redlich-Peterson }\end{array}$ & 0.23722 & 0.992 \\
\hline $\mathrm{CCAC}_{\mathrm{KOH}}$ & $\begin{array}{l}\mathrm{q}_{\mathrm{ms}}(\mathrm{mg} / \mathrm{g}) \\
4.697 \times 10^{4}\end{array}$ & $\begin{array}{l}a_{s}(L / g) \\
0.06374\end{array}$ & $\begin{array}{l}\mathrm{B}_{\mathrm{s}} \\
0.6867\end{array}$ & $\begin{array}{l}\mathrm{R} \\
0.9915\end{array}$ & $\begin{array}{l}\mathrm{A} \\
7.583 \times 10^{3}\end{array}$ & $\begin{array}{l}\text { B } \\
1.67197\end{array}$ & $\begin{array}{l}\text { B } \\
0.5428\end{array}$ \\
\hline
\end{tabular}

Table 3 showed that Freundlich isotherm model had the best fit to the experimental data with a $\mathrm{R}^{2}$ value of 0.999 , thus suggesting the formation of multilayer coverage of crude oil onto the heterogeneous distribution of active sites on the surface of $\mathrm{CCAC}_{\mathrm{KOH}}[49,42]$. The $\mathrm{K}_{\mathrm{f}}$ value was $2.82 \times 10^{3}$ $\mathrm{mg} / \mathrm{g}$ indicating that as the $\mathrm{K}_{\mathrm{f}}$ value increased, the adsorption capacity of $\mathrm{CCAC}_{\mathrm{KOH}}$ also increased. According to [50], the adsorption is favourable when $1<\mathrm{n}<10$, and the higher the $\mathrm{n}$ value, the stronger the adsorption intensity, thus the value of $n$ was greater than unity (i.e, $n=1.63$ ) indicating that the crude oil was favourably adsorbed on $\mathrm{CCAC}_{\mathrm{KOH}}$. On the contrary, a lower correlation coefficient for Temkin model $\left(\mathrm{R}^{2}=0.9621\right)$ was observed which indicated unsatisfactory fitting between the experimental data and the isotherm model equations for $\mathrm{CCAC}_{\mathrm{KOH}}$.

\subsection{Batch Adsorption Kinetics}

In order to investigate the mechanism of sorption and potential rate-controlling steps such as mass transport and chemical reaction processes involved in the crude oil adsorption from the aqueous solution, several kinetic models such as the pseudo-first order, pseudo-second order and intraparticle diffusion and Boyd models were used for the analysis. The adsorption kinetic model constants for the removal of crude oil are shown in Table 4. The result in Table
4 showed that the correlation coefficients for the pseudosecond order kinetic model for $\mathrm{CCAC}_{\mathrm{KOH}}\left(\mathrm{R}^{2}=0.999\right)$ was much higher and closer to unity than that of pseudo-first order kinetic model and intra-particle diffusion, thus; concluded that the adsorption behaviour of crude oil on $\mathrm{CCAC}_{\mathrm{KOH}}$ predominantly followed pseudo-second order kinetic model.

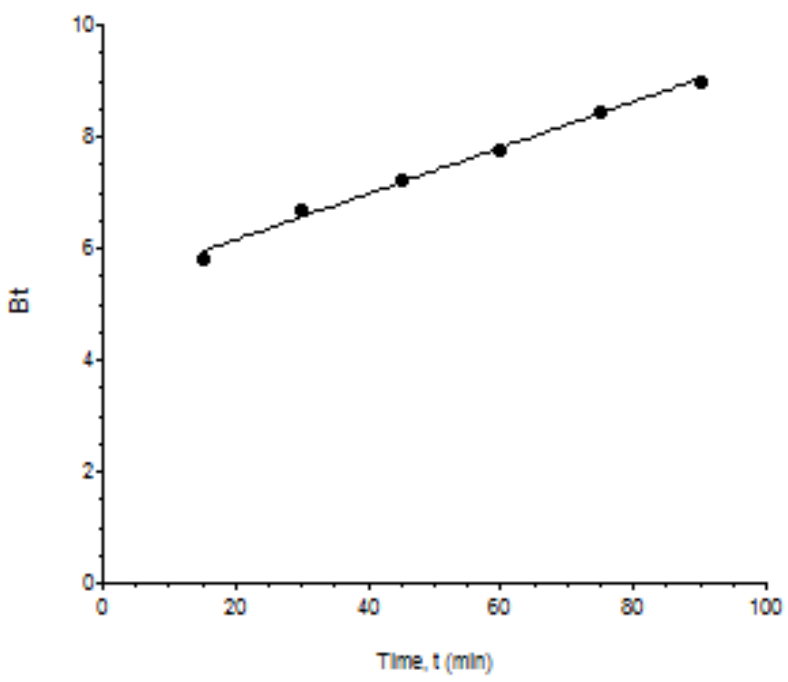

Figure 9. Boyd plot for the adsorption of crude oil onto $C C A C_{K O H}$.

Table 4. Adsorption kinetic model constants for the removal of crude oil using $C С A C_{K О Н}$.

\begin{tabular}{|c|c|c|c|c|c|c|c|}
\hline \multirow{2}{*}{ Adsorbent } & \multirow{2}{*}{$q_{e, \exp }(m g / g)$} & \multicolumn{3}{|c|}{ Pseudo-first order } & \multicolumn{3}{|c|}{ Pseudo-second order } \\
\hline & & $K_{\mathrm{f}}(\mathrm{g} / \mathrm{mg} \cdot \mathrm{min})$ & $q_{e, c a l}(\mathrm{mg} / \mathrm{g})$ & $\mathbf{R}^{2}$ & $K_{\mathrm{s}}$ (g/mg.min) & $q e_{, \text {cal }}(\mathrm{mg} / \mathrm{g})$ & $\mathbf{R}^{2}$ \\
\hline $\mathrm{CCAC}_{\mathrm{KOH}}$ & 4859.25 & 0.430698 & 4858.092 & 0.846 & 0.00659 & 4857.138 & 0.999 \\
\hline Adsorbent & $\mathrm{q}_{\mathrm{e}, \exp }(\mathrm{mg} / \mathrm{g})$ & $\begin{array}{l}\text { Intra-particle Dif } \\
\mathrm{K}_{\mathrm{ip}}\left(\mathrm{mg} / \mathrm{g} \cdot \mathrm{min}^{1 / 2}\right)\end{array}$ & $\mathrm{C}(\mathrm{mg} / \mathrm{g})$ & $\mathrm{q}_{\mathrm{e}, \text { cal }}(\mathrm{mg} / \mathrm{g})$ & $\mathrm{R}^{2}$ & & \\
\hline $\mathrm{CCAC}_{\mathrm{KOH}}$ & 4859.25 & 1.107923676 & 4848.39 & 4859.747 & 0.8499 & & \\
\hline
\end{tabular}

This also elucidated the fact that the overall rate of adsorption process was controlled by chemisorption which involved co-valent forces through the sharing or exchange of electrons between the adsorbents and crude oil molecules and also that the rates of surface reaction, chemical reaction (chemisorption) and transport of crude oil from liquid to adsorbent phase was faster due to the high hydrophobic nature of the modified adsorbents [28, 51].

Eba et al. (2010) stated that the larger the intercept (boundary layer effect; C) for intra-particle diffusion model, the greater the contribution of the surface sorption in the ratecontrolling step [52]. This implied that the correlation coefficient and thickness of the boundary layer for $\mathrm{CCAC}_{\mathrm{KOH}}$
$\left(\mathrm{R}^{2}=0.8499 ; \mathrm{C}=4848.39 \mathrm{mg} / \mathrm{g}\right)$ validated the existence of some degree of boundary layer control in the adsorption process which also indicated that the intra-particle diffusion was not the only rate-limiting step, but other processes might as well have controlled the rate of adsorption.

The Boyd model which is widely used for studying the mechanism of adsorption was also used to determine whether the main resistance to mass transfer was in the thin film (boundary layer) surrounding the adsorbent particle or in the resistance to diffusion inside the pores. The linearity test of the plot of $B_{t}$ against time was used to distinguish between the film and particle-diffusion controlled adsorption mechanism as shown in Figure 9. 
If the plot is a straight line passing through the origin, the adsorption rate was governed by the particle diffusion; otherwise it was governed by the film diffusion [53]. This deviation may be due to the difference in mass transfer rate in the initial and final stages of adsorption [54]. Figure 9 showed the Boyd plot for the crude oil adsorption onto $\mathrm{CCAC}_{\mathrm{KOH}}$ to be a linear graph which does not pass through the origin, thus confirming that the adsorption mechanism was film-diffusion controlled.

\subsection{Thermodynamic Studies}

The thermodynamics parameters were evaluated to confirm the nature of the adsorption. The effect of temperature on the adsorption of crude oil onto $\mathrm{CCAC}_{\mathrm{KOH}}$ was evaluated over the temperature range of $296-304 \mathrm{~K}$. As shown in Table 5 , the adsorption capacity and \% removal of crude oil increased with an increase in temperature which indicates that the process was endothermic.

Table 5. Thermodynamics studies on the removal of crude oil using $C С A C_{K O H}$.

\begin{tabular}{|c|c|c|c|c|c|c|}
\hline Temperature (K) & $\mathrm{q}_{\mathrm{e}}(\mathrm{mg} / \mathrm{g})$ & $\%$ removal of crude oil & $\Delta \mathrm{G}^{\mathbf{0}}(\mathrm{KJ} / \mathrm{mol})$ & $\Delta \mathbf{H}^{\mathbf{0}}(\mathrm{KJ} / \mathrm{mol})$ & $\Delta S^{0}(\mathbf{K J} / \mathrm{mol} . \mathrm{K})$ & Ea $(\mathrm{KJ} / \mathrm{mol})$ \\
\hline 296 & 4857.55000 & 99.94959 & -18.68400 & 134.33760 & 0.51721 & 134.33760 \\
\hline 298 & 4858.52500 & 99.96965 & -20.06790 & 134.33760 & 0.51721 & 134.33760 \\
\hline 300 & 4858.82500 & 99.97582 & -20.76990 & 134.33760 & 0.51721 & 134.33760 \\
\hline 304 & 4859.50000 & 99.98971 & -23.20670 & 134.33760 & 0.51721 & 134.33760 \\
\hline
\end{tabular}

The values of the thermodynamics parameters determined at different temperatures are listed in Table 5. The negative values of $\Delta \mathrm{G}^{\circ}$ at different temperature indicated that the adsorption was thermodynamically feasible and was a spontaneous process and also the decrease in the $\Delta \mathrm{G}^{\mathrm{o}}$ values with increasing temperature indicated an increase in the feasibility and spontaneity of the adsorption at higher temperatures [55].

The positive values of $\Delta \mathrm{H}^{\mathrm{o}}$ for $\mathrm{CCAC}_{\mathrm{KOH}}\left(\Delta \mathrm{H}^{\mathrm{o}}=134\right.$ $\mathrm{KJ} / \mathrm{mol}$ ) implied that the adsorption reaction of crude oil was endothermic in nature. This was as a result of increasing the temperature which led to a corresponding increase in the rate of diffusion of the crude oil molecules across the external boundary layer and in the internal pores of the adsorbent particles, owing to the decrease in the viscosity of the solution [47]. Furthermore, an increase in both \% removal of crude oil and adsorption capacity at higher temperature was possibly due to the increase in pore size distribution and also due to an increase in kinetic forces; that is, the mobility of the crude oil species inside the adsorbent matrix [48]. It was depicted also that the active surface sites increased proportionally with the increase in temperature [56].

According to Abidin et al. (2011), the magnitude of the enthalpy is about 20 to $40 \mathrm{KJ} / \mathrm{mol}$ for physisorption and 60 to $400 \mathrm{KJ} / \mathrm{mol}$ for chemisorption [57]. Therefore, the adsorption of crude oil onto $\mathrm{CCAC}_{\mathrm{KOH}}$ can be classified as chemisorption since its absolute magnitude of enthalpy is 134 $\mathrm{KJ} / \mathrm{mol}$, which shows that it is in the range of chemisorption. The positive values of $\Delta S^{o}$ for $\mathrm{CCAC}_{\mathrm{KOH}}\left(\Delta \mathrm{S}^{\mathrm{o}}=0.517\right.$ $\mathrm{KJ} / \mathrm{mol} . \mathrm{K})$ signified that there was an increase in disorderliness and randomness at the adsorbent-adsorbate interface during the adsorption of crude oil from water due to the highly ordered crude oil molecules in the hydrophobic layer of $\mathrm{CCAC}_{\mathrm{KOH}}$ at adsorption equilibrium; thus resulting in a gain of more translational entropy [58, 59].

Morrison et al. (2011) defined activation energy, Ea, as the minimum kinetics energy needed by the adsorbate molecules to react with the active sites available on the surface of the adsorbent [60]; hence, the large value of $\mathrm{E}_{\mathrm{a}}$ for $\mathrm{CCAC}_{\mathrm{KOH}}\left(\mathrm{E}_{\mathrm{a}}\right.$ $=134.338 \mathrm{KJ} / \mathrm{mol}$ ) showed the presence of high energy barrier to initiate the reaction which also verified that the adsorption of crude oil onto $\mathrm{CCAC}_{\mathrm{KOH}}$ is a chemical adsorption. This is so since the values of $E_{a}$ are consistent with the fact that the magnitude of the activation energy for chemical adsorption is usually between 40 and $400 \mathrm{KJ} / \mathrm{mol}$ $[61,62]$.

These results were also consistent with the values of enthalpy in Table 5, which indicated that the crude oil adsorption on $\mathrm{CCAC}_{\mathrm{KOH}}$ took place via chemical adsorption. These results demonstrate that the thermodynamic behaviours of an adsorption system are dependent on the type of adsorbent and adsorbate being investigated. It is also influenced by the particle size or physical form of the adsorbent, its physical properties and the surface functional groups of the adsorbent as well as the characteristics and nature of the adsorbate.

\section{Conclusions}

In conclusion, $\mathrm{CCAC}$ when activated with $\mathrm{KOH}$ showed great potentials to be used as alternative adsorbent in the adsorption of spilled crude oil in water. The advantage of chemical modification of CCAC was that it yields high value of adsorption capacities and \% removal of crude oil and the use of CCAC as adsorbent showed that it is readily available, cost effective, non-toxic and environmentally-friendly and hence, the determined parameters for the adsorption process could be useful for the design of industrial plants for oil spill clean-up. The pre-treatment of CCAC with $\mathrm{KOH}$ effectively enhanced its surface hydrophobicity, thus increased the adsorption capacity and \% removal of crude oil. FTIR and SEM analysis elucidated significant adsorption/uptake of crude oil from water onto $\mathrm{CCAC}_{\mathrm{KOH}}$. The adsorption of spilled crude oil onto $\mathrm{CCAC}_{\mathrm{KOH}}$ exhibited pseudo-second order kinetics and was controlled by film-diffusion and governed by the internal transport mechanism. All the experimental data fitted well with the non-linear Freundlich isotherm model. The thermodynamic studies proved the feasibility, spontaneity and endothermic nature of the adsorption which was controlled by a chemisorption process. 


\section{Appendix}

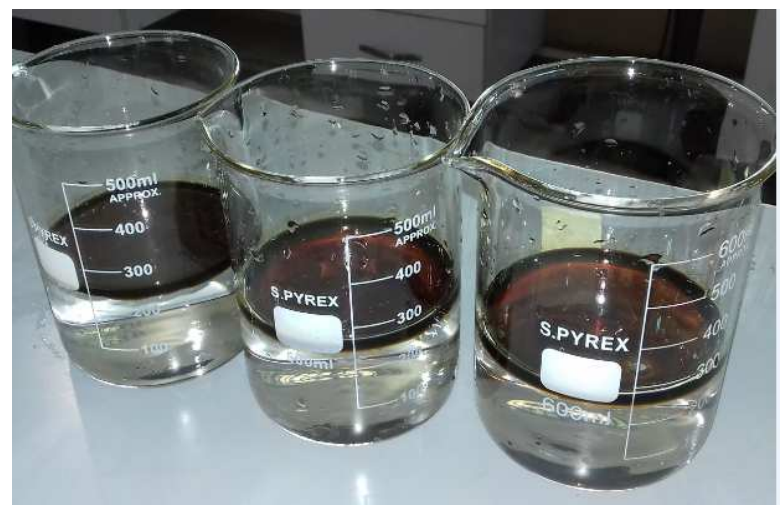

Figure A1. Simulated oil spill for batch adsorption experiment.

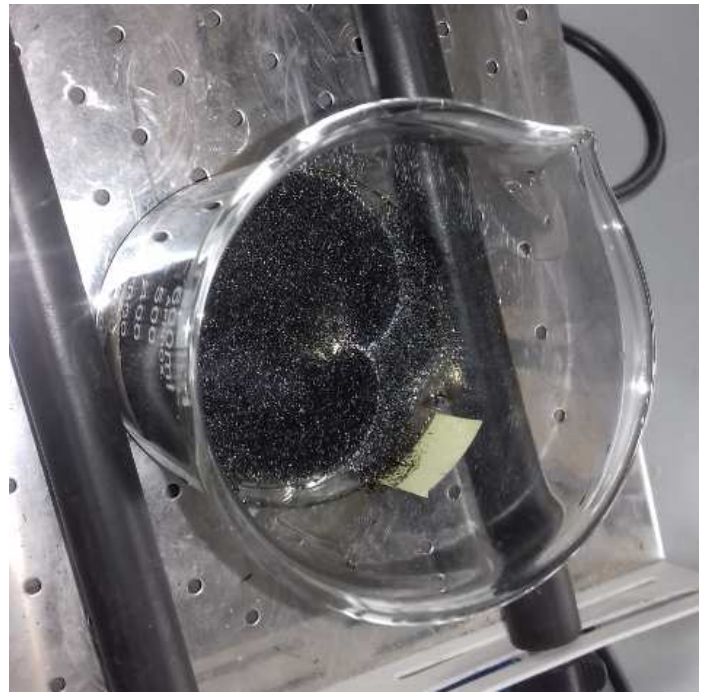

Figure A2. Batch adsorption experiment of crude oil removal using CCAC.

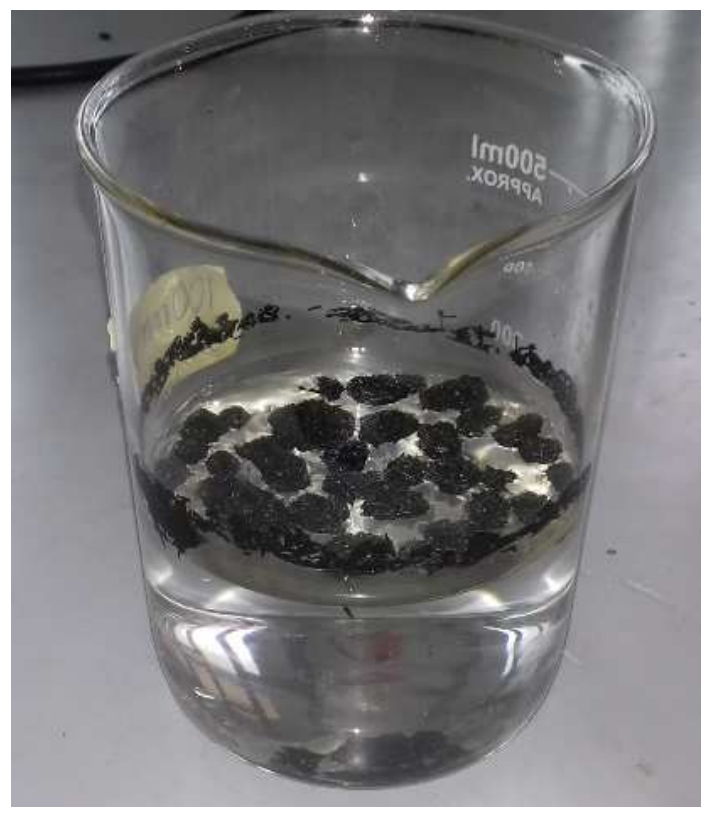

Figure A3. Adsorbed crude oil using CCAC after batch adsorption experiment.

\section{References}

[1] Abdelwahab, O. (2014). Assessment of raw luffa as a natural hollow oleophilic fibrous sorbent for oil spill clean-up. National Institute of Oceanography and Fisheries, Alexandria, Egypt. Alexandria Engineering Journal, 53: 213-218.

[2] Allan, S. E., Smith, B. W., Anderson, K. A. (2012). Impact of the deep-water horizon oil spill on bioavailable polycyclic aromatic hydrocarbons in Gulf of Mexico coastal waters. Environmental Science and Technology, 46: 2033-2039.

[3] Al-Majed, A. A., Adebayo, A. R. and Hossain, M. E. (2012). A sustainable approach to controlling oil spills. Journal of Environmental Management, 113: 213-27.

[4] Kingston, P. F. (2002). Long-term environmental impact of oil spills. Bulletin of Spill Science and Technology, 7: 53-61.

[5] Tamis, J. E., Jongbloed, R. H., Karman, C. C., Koops, W. and Murk, A. J. (2011). Rational application of chemicals in response to oil spills may reduce environmental damage. Integrated Environmental Assessment and Management, 8: 231-241.

[6] National Response Team Science and Technology Committee, (2007). Application of sorbents and solidifiers for oil spills. North Chelmsford, MA. 31p.

[7] Deschamps, G., Caruel, H., Borredon, M., Bonnin, C. and Vignoles, C. (2003). Oil removal from water by selective sorption on hydrophobic cotton fibres. Study of sorption properties and comparison with other cotton fibre-based sorbents. Environmental Science and Technology Journal, 37: 1013-1015.

[8] Tsai, W. T., Chang, C. Y., Wang, S. Y., Chang, C. F., Chien, S. F. and Sun, H. F. (2001). Utilization of agricultural waste corn cob for the preparation of carbon adsorbent. Journal of Environmental Science and Health, 36 (5): 677-686.

[9] Karan, C., Rengasamy, R. and Das, D. (2011). Oil spill cleanup by structured fibre assembly. Indian Journal of fibre and textile resources, 36: 190-200.

[10] Tay, J. H., Chen, X. G., Jeyaseelan, S. and Graham, N. (2001). Optimizing the preparation of activated carbon from digested sewage sludge and coconut coir. Chemosphere, 44: 45-51.

[11] Lim, T. T. and Huang, X. (2007). Evaluation of kapok (Ceiba pentandra (L.) Gaertn.) as a natural hollow hydrophobicoleophilic fibrous sorbent for oil spill clean-up. Chemosphere, 66 (5): 955-963.

[12] Tan, I. A. W., Hameed, B. H. and Ahmad, A. L. (2008). Optimization of preparation conditions for activated carbons from coconut coir using response surface methodology. Chemical Engineering Journal, 137: 462-470.

[13] Manju, G. N., Raji, C. and Anirudhan, T. S. (1998). Evaluation of coconut coir carbon for the removal of arsenic from water. Water Resources, 32 (10): 3062-3070.

[14] Phan, N. H., Rio, S., Faur, C., Coq, L. L. P., Cloirec, L. and Nguyen, T. H. (2006). Production of fibrous activated carbons from natural cellulose (jute, coconut) fibres for water treatment applications. Carbon, 44: 2569-2577. 
[15] ASTM, D 2867-91 (1991). Standard test methods for moisture in activated carbon. American Society of Testing and Materials. ASTM Committee on Standards. Philadelphia, PA. $10 \mathrm{p}$.

[16] ASTM, D 5832-98. (1999). Standard test method for volatile content of activated carbon. American Society of Testing and Materials. ASTM Committee on Standards. Philadelphia, PA. $12 \mathrm{p}$.

[17] ASTM, D 2866-94. (1999). Standard test method for Ash content of activated carbon. American Society of Testing and Materials. ASTM Committee on Standards. Philadelphia, PA. 8 p.

[18] ASTM, D 2854-96. (1999). Standard test method for Apparent density of activated carbon. American Society of Testing and Materials. ASTM Committee on Standards. Philadelphia, PA. $5 \mathrm{p}$.

[19] ASTM, D 3838-80 (1996). Refractories, Carbon and Graphic products; Activated carbon. American Society for Testing and Materials. Annual book of ASTM Standard, 15.01, ASTM, Philadelphia, PA. 14p.

[20] Nwabanne, J. T. and Igbokwe, P. K. (2012). Application of response surface methodology for preparation of activated carbon from Palmyra palm nut. New York Science Journal, 5 (9): 18-25.

[21] Olufemi, B. A., Jimoda, L. A. and Agbodike, N. F. (2014). Adsorption of crude oil using meshed corncobs. Asian Journal of Applied Science and Engineering, 3: 63-75.

[22] Abowei, J. F. N. (2010). Salinity, dissolved oxygen, pH and surface water temperature conditions in Nkoro River, Niger Delta, Nigeria. Advanced Journal of Food Science and Technology, 2 (1): 36-40.

[23] Daud, W. M. A. W. and Ali, W. S. W. (2004). Comparison on pore development of activated carbon produced from palm shell and coconut shell. Bioresource Technology, 93: 63-69.

[24] Yang, K., Peng, J., Srinivasakannan, C., Zhang, L., Xia, H. and Duan, X. (2010). Preparation of high surface area activated carbon from coconut shells using microwave heating. Bioresource Technology, 101: 6163-6169.

[25] Valix, M. Cheung, W. H. and McKay, G. (2004). Preparation of activated carbon using low temperature carbonization and physical activation of high ash raw baggase for acid dye adsorption. Chemosphere, 56: 493-501.

[26] Pavia, G. S. and Lampman, G. M. (2009). Introduction to spectroscopy, 4th Edition, Scitech B. News, 322p.

[27] Adebajo, M. O. and Frost, R. L. (2004). Acetylation of raw cotton for oil spill clean-up application: An FTIR and 13C MAS NMR spectroscopic investigation. Spectrochimica Acta, Part A: Molecular Biomolecular Spectroscopy, 60 (10): 23152321.

[28] Onwuka, J. C., Agbaji, E. B., Ajibola, V. O. and Okibe, F. G. (2018). Treatment of crude oil contaminated water with chemically modified natural fibre. Applied Water Science Journal, 8 (86): 1-10.

[29] Mopoung, S., Moonsri, P., Palas, W. and Khumpai, S. (2015). Characterization and properties of activated carbon prepared from tamarind seeds by $\mathrm{KOH}$ activation for $\mathrm{Fe}(\mathrm{III})$ adsorption from aqueous solution. The Scientific World Journal, 10
(1155): 415961.

[30] Azeh, Y., Olatunji, G. A., Mohammed, C. and Mamza, P. A. (2013). Acetylation of wood flour from four wood species grown in Nigeria Using vinegar and acetic anhydride. International Journal of Carbohydrate Chemistry, 20 (2): 8596.

[31] Onwuka, J. C., Agbaji, E. B., Ajibola, V. O. and Okibe, F. G. (2016). Kinetic studies of surface modification of lignocellulosic Delonix regia pods as sorbent for crude oil spill in water. Journal of Applied Resource Technology, 14: 415-424.

[32] Chung, S., Suidan M. T., Venosa, A. D. (2011). Partially acetylated sugarcane bagasse for wicking oil from contaminated wetlands. Chemical Engineering Technology, 34 (12): 1989-1996.

[33] Rocha, C. G., Zaia, D. A.., Alfaya, R. V. and Alfaya, A. A. (2009). Use of rice straw as biosorbent for removal of $\mathrm{Cu}$ (II), $\mathrm{Zn}$ (II), Cd (II) and Hg (II) ions in industrial effluents. Journal of Hazardous Materials, 166: 383-388.

[34] Kudaybergenov, K. K., Ongarbayev, E. K. and Mansurov, Z. A. (2012). Thermally treated rice coirs for petroleum adsorption. International Journal of Biological Chemistry, 1: $3-12$.

[35] Olufemi, B. A. and Otolorin, F. (2017). Comparative adsorption of crude oil using mango (mangnifera indica) shell and mango shell activated carbon. Environmental Engineering Research, 11: 1-27.

[36] Thompson, N. E., Emmanuel, G. C., Adagadzu, K. J. and Yusuf, N. B. (2010). Sorption studies of crude oil on acetylated rice coirs. Scholars research library. Archives of Applied Science Research, 2 (5): 142-151.

[37] Elkady, M. F., Hussien, M. and Abou-rady, R. (2015). Equilibrium and kinetics behaviour of oil spill process onto synthesized nano-activated carbon. American Journal of Applied Chemistry, 3 (3-1): 22-30.

[38] Itodo, H. U. and Itodo, A. U. (2010). Surface coverage and adsorption study of dye uptake by derived acid and base treated mango seed shells. Journal of Chemical and Pharmaceutical Research, 2 (3): 673-683.

[39] Rajakovic, O. V., Aleksic, G. and Rajakovic, L. (2008). Governing factors for motor oil removal from water with different sorption materials. Journal of Hazardous Materials, 154 (1-3): 558-563.

[40] Sulyman, M., Sienkiewicz, M., Haponiuk, J. and Zalewski, S. (2018). New approach for adsorptive removal of oil in wastewater using textile fibers as alternative adsorbent. Acta Scientific Agriculture, 2 (6): 1-6.

[41] Ahmad, A. L., Sumathi, S. and Hameed, B. H. (2005). Adsorption of residue oil from palm oil mill effluent using powder and flake chitosan: equilibrium and kinetic studies. Water Resources, 39 (12): 2483-2494.

[42] Sidik, S. M., Jalil, A. A., Triwahyono, S., Adam, S. H., Satar, M. A. H. and Hameed, B. H. (2012). Modified oil palm leaves adsorbent with enhanced hydrophobicity for crude oil removal. Chemical Engineering Journal, 203: 9-18.

[43] Wang, J., Zheng, Y. and Wang, A. (2012). Effect of kapok fibre treated with various solvents on oil absorbency. Industrial Crops and Products Journal (Elsevier), 40: 178184. 
[44] Williams, N. E. and Nur, P. A. (2018). KOH modified Thevetia peruviana shell activated carbon for sorption of dimethoate from aqueous solution. Journal of Environmental Science and Health, pp: 2-15.

[45] Lim, T. T. and Huang, X. (2006). In situ oil/water separation using hydrophobic-oleophilic fibrous wall: a lab-scale feasible study for groundwater clean-up. Journal of Hazardous Materials, 137: 820-826.

[46] Lin, C. C. and Liu, H. S. (2000). Adsorption in a centrifugal field: Basic dye adsorption by activated carbon. Industrial Engineering and Chemistry Resources, 39: 161-167.

[47] Wang, S. and Zhu, Z. (2007). Effects of acidic treatment of activated carbons on dye adsorption. Dyes pigment, 75: 306314.

[48] Senthilkumaar, S., Kalaamani, P., Porkodi, K., Varadarajan, P. R. and Subburaam, C. V. (2006). Adsorption of dissolved Reactive red dye from aqueous phase onto activated carbon prepared from agricultural waste. Bioresource Technology, 97: $1618-1625$.

[49] Gobi, K., Mashitah, M. D. and Vadivelu, V. M. (2011). Adsorptive removal of Methylene Blue using novel adsorbent from palm oil mill effluent waste activated sludge: equilibrium, thermodynamics and kinetics studies. Chemical Engineering Journal, 171: 1246-1252.

[50] Lu, Z., Maroto-Valer, M. M. and Schobert, H. H. (2010). Catalytic effects of inorganic compounds on the development of surface areas of fly ash carbon during steam activation. Fuel Processing Technology, 89: 3436-3441.

[51] Tan, I. A. W and Hameed, B. H. (2010). Adsorption isotherms, kinetics, thermodynamics and desorption studies of basic dye on activated carbon derived from oil palm empty fruit bunch. Journal of Applied Sciences, 10 (21): 2565-2571.

[52] Eba, F., Gueu, S., Eya'A-Mvongbote, A., Ondo, J. A., Yao, B. K., Ndong, N. J. and Kouya, B. R. (2010). Evaluation of the absorption capacity of the natural clay from Bikougou (Gabon) to remove $\mathrm{Mn}(\mathrm{II})$ from aqueous solution. International Journal of Engineering and Science Technology, 2 (10): 50015016.
[53] Hameed, B. H. and El-Khaiary, M. I. (2009). Malachite green adsorption by rattan sawdust: isotherm, kinetics and mechanism modelling. Journal of Hazardous Materials, 162: 344-350.

[54] Mohanty, K., Das, D. and Biswas, M. N. (2005). Adsorption of phenol from aqueous solutions using activated carbons prepared from tectona grandis sawdust by $\mathrm{ZnCl}_{2}$ activation. Chemical Engineering Journal, 115: 121-131.

[55] Auta, M. and Hameed, B. H. (2011). Preparation of waste tea activated carbon using potassium acetate as an activating agent for adsorption of Acid Blue 25 dye. Chemical Engineering Journal, 171: 502-509.

[56] Bulut, Y. and Zeki, T. (2007). Removal of heavy metals from aqueous solution by sawdust adsorption. Journal of Environmental Science, 19: 160-166.

[57] Abidin, M. A. Z., Jalil, A. A., Triwahyono, S., Adam, S. H. and Kamarudin, N. H. N. (2011). Recovery of Gold(III) from an aqueous solution onto a Durio zibethinus coir. Biochemical Engineering Journal, 54: 124-131.

[58] Gopal, V. and Elango, K. P. (2007). Kinetic and thermodynamic investigations of adsorption of Fluoride onto activated Aloe Vera carbon. Journal of Indian Chemical Engineering Society, 84 (11): 1114-1118.

[59] Gupta, V. K., Ganjali, M., Nayak, A., Bhushan, B. and Agarwal, S. (2012). Enhanced heavy metals removal and recovery by mesoporous adsorbent prepared from waste rubber tire. Chemical Engineering Journal, 197: 330-338.

[60] Morrison, R. T., Boyd, R. N. and Bhattacharjee, S. K. (2011). Organic Chemistry. 7th Edition. Pearson Education Inc., Dorling Kindersley (India) Pvt. Ltd. 1441p.

[61] Fomkin, A. (2009). Nano-porous material and their adsorption properties. Institute of Physical Chemistry and Electrochemistry. Russian Academy of Sciences, 45: 133-149.

[62] Li, Q., Chai, L., Yang, Z. and Wang, Q. (2009). Kinetics and thermodynamics of $\mathrm{Pb}(\mathrm{II})$ adsorption onto modified spent grain from aqueous solutions. Applied Surface Sciences, 255: 4298-4303. 